\title{
The Analysis of Level of Consciousness on the Protected Areas in Sample of Ölüdeniz
}

\author{
Zeynep R. Bozhüyük Ardahanlığlu1, Esra Özhancı², Tendü Hilal Göktuğ ${ }^{*}$ \\ ${ }^{1}$ Landscape and Ornamental Plants Programme, Fethiye A.S.M.K Vocational High School, \\ Muğla Sitki Koçman University, Fethiye, Turkey \\ ${ }^{2}$ Department of Landscape Architecture, Faculty of Architecture and Design, Ataturk University, Erzurum, \\ Turkey \\ ${ }^{3}$ Landscape Architecture Department, Faculty of Agriculture, Adnan Menderes University, South Campus, \\ Aydın, Turkey \\ Email: zeyneprb@gmail.com, eozhanci@atauni.edu.tr,
}

Received 14 June 2014; revised 29 July 2014; accepted 14 August 2014

Copyright (C 2014 by authors and Scientific Research Publishing Inc.

This work is licensed under the Creative Commons Attribution International License (CC BY). http://creativecommons.org/licenses/by/4.0/

\section{(c) (1) Open Access}

\begin{abstract}
Ölüdeniz is a town of Fethiye, the district of Muğla. It is $128 \mathrm{~km}$. away from Muğla and $12 \mathrm{~km}$. away from Fethiye. The region which is located within the boundaries of Kumburnu and Belceğiz beaches has been declared as a Natural Park in 1983. Ölüdeniz is an important center for many domestic and foreign tourists to visit in the tourism season. The purpose of this study was to investigate the awareness of the domestic tourists on the preservation status. In this study, 100 questionnaires were completed by participants in ölüdeniz. The study was carried out in July, 2013. The survey questions were related to the person's individual characteristics, the level of awareness of conservation status. According to the results of the survey, it is revealed that the majority of domestic tourists come to ölüdeniz just to visit the area; they are not aware of any preservation status, and also some domestic tourists have never been to Fethiye and a lot of places around Fethiye. Lastly, considering the distribution of regional visitors from across the country, the results showed a homogeneous distribution. According to the results, it is determined that, the domestic tourists have not so much information especially about the preservation status, and thus some solutions are presented in order to increase domastic tourists level of awareness on the conservation status and levels of awareness.
\end{abstract}

\section{Keywords}

Protected Areas, Fethiye, Ölüdeniz, Tourism

\footnotetext{
${ }^{*}$ Corresponding author.
}

How to cite this paper: Ardahanlıoğlu, Z.R.B., Özhancı, E. and Göktuğ, T.H. (2014) The Analysis of Level of Consciousness on the Protected Areas in Sample of Ölüdeniz. Open Journal of Social Sciences, 2, 95-103. 


\section{Introduction}

Rapid population growth and the excessive and irresponsible consumption caused by this increase is increasing the pressure on natural resources day by day. According to the degree of the impact of this pressure, it brings about the destruction of natural resources and may cause unrecoverable consequences. Sustainable use of natural resources will only be provided through an effective understanding of protection. According to Basal (1998), protecting the nature and the land we live on, benefiting the existing potential at the maximum level and being able to offer it progressively to the benefit of the next generation may only be possible by examining and elaborating the usage options that do not contradict with each other and ensuring controls of them with their implementation based on a plan [1]. The concept of protection is basically a set of measures needed to sustain life and developed in order to prevent the extinction of future resource values over time, and determining the optimum methods of use [2].

According to IUCN (The International Union for Conservation of Nature) (2011), A protected area is a clearly defined geographical space, recognised, dedicated and managed, through legal or other effective means, to achieve the long term conservation of nature with associated ecosystem services and cultural values [3]. In our country, protected areas are assessed within Forest Law No. 6831, National Parks Act No. 2873, Hunting Act No. 4915, Cultural and Natural Heritage Protection Act No. 2863, Fisheries Act No. 1380, Zoning Law No. 3194 and Environmental Law No. 2872. The important natural areas in our country are protected with 18 different conservation statuses. And sometimes even a few conservation statuses are given to a single area. Some of them have been declared according to the national legislation, and some have been created on the basis of international agreements [4].

The Nature Park, with this conservation status, was declared as first-degree Natural Site, and our area of study with three different conservation statuses, as well as being within the boundary of Fethiye-Gocek Special Environmental Protection Area, was declared as a nature park in 1983. Ölüdeniz-Kidrak Natural Park has been given the status in order to protect the region's wealth of flora and the natural landscape formed by forests, the sea and cliffs. This study was conducted with the purpose of determining especially the awareness of domestic tourists on conservation status in Ölüdeniz-Kıdrak Natural Park, which combines many values within.

\section{Materials and Methods}

\subsection{Material}

The town of Ölüdeniz is surrounded by Fethiye district in the North, Faralya village and the Mediterranean in the South and Kayaköy in the West and Mount Mendos in the East. Ölüdeniz is a touristic center located at the intersection of the Aegean Sea and the Mediterranean Sea, in the western end of the Mediterranean region. Ölüdeniz comprises a total area of $107 \mathrm{~km}^{2}$ covering the Southern part of the Fethiye district center, Ovacık, Belcegiz and Hisaronu neighbourhoods of Ölüdeniz Municipality, and the settling of Kayakoy [5]. ÖlüdenizKıdrak Natural Park, located within the boundaries of Ölüdeniz resort, forming the study area, is located within the boundaries of the Special Environmental Protection and is also a first degree natural protected area. The Natural Park is $16 \mathrm{~km}$ away from Fethiye town centre and the size of the area is 950 hectares. Before the 1980s, it was used as a recreation area in the forest. On 29.12.1983, it was declared as a Natural Park in order to protect the region's wealth of flora and the natural landscape formed by the forests, sea and cliffs (Figure 1).

\subsection{Method}

In this study trying to examine the awareness levels of domestic tourists on conservation status in ÖlüdenizKıdrak Natural Park, in the first stage as a priority, the information about the source values, sporting opportunities and general status of the Natural Park was given by performing data and literature collection about Ölüdeniz-Kidrak Natural Park. In the next phase; the strengths, weaknesses, opportunities and threats were identified by performing a SWOT analysis [6] [7] on the Natural Park. In July 2013, the data of the survey conducted with 100 domestic tourists was assessed by SPSS (Statistical Packet for Social Sciences) package program and a Chi-Square test was applied [8]. In the last phase of the study, several solutions were offered in the light of the findings (Table 1). 


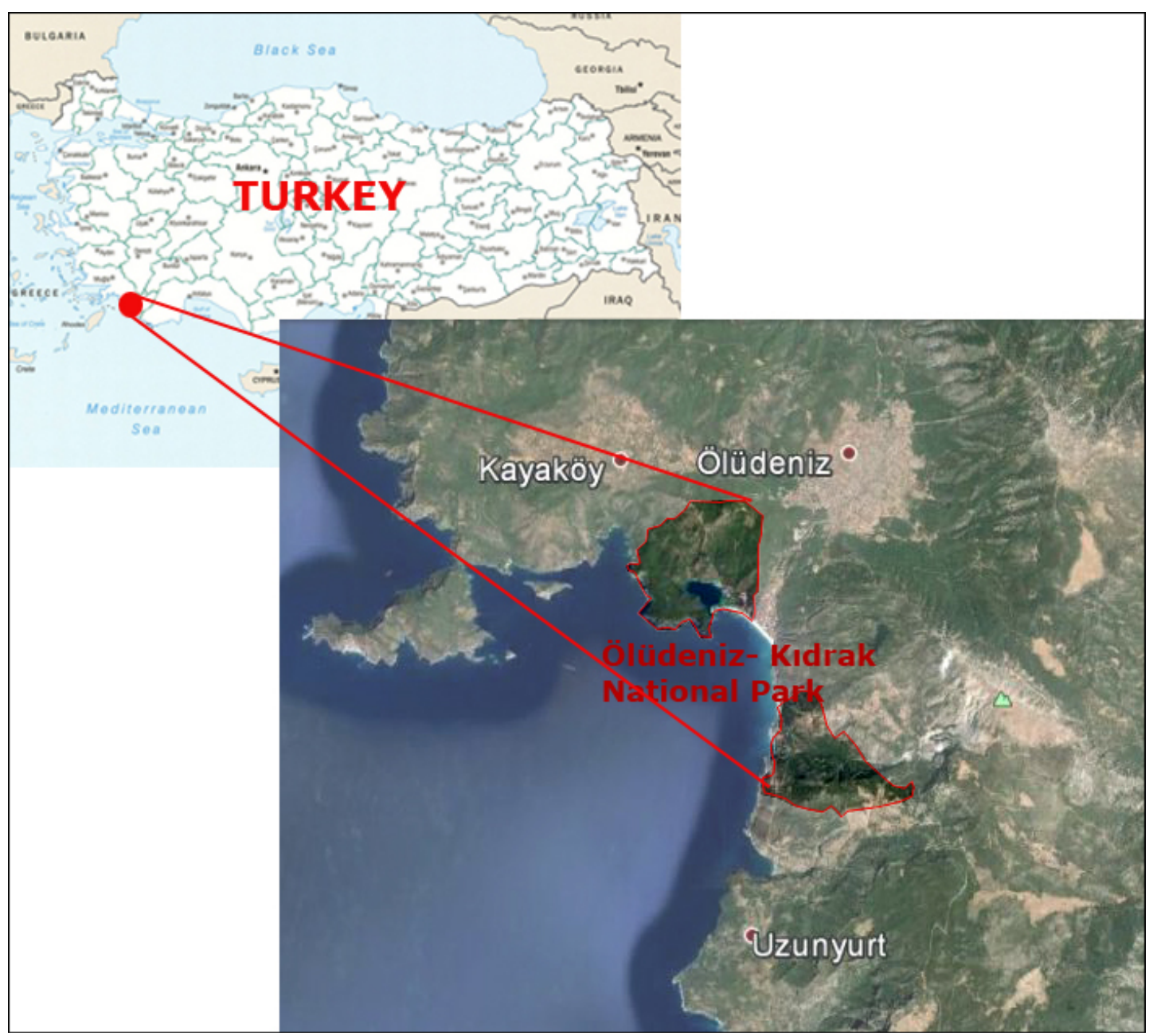

Figure 1. Ölüdeniz-Kıdrak Natural Park location map.

Table 1. Method flowchart.

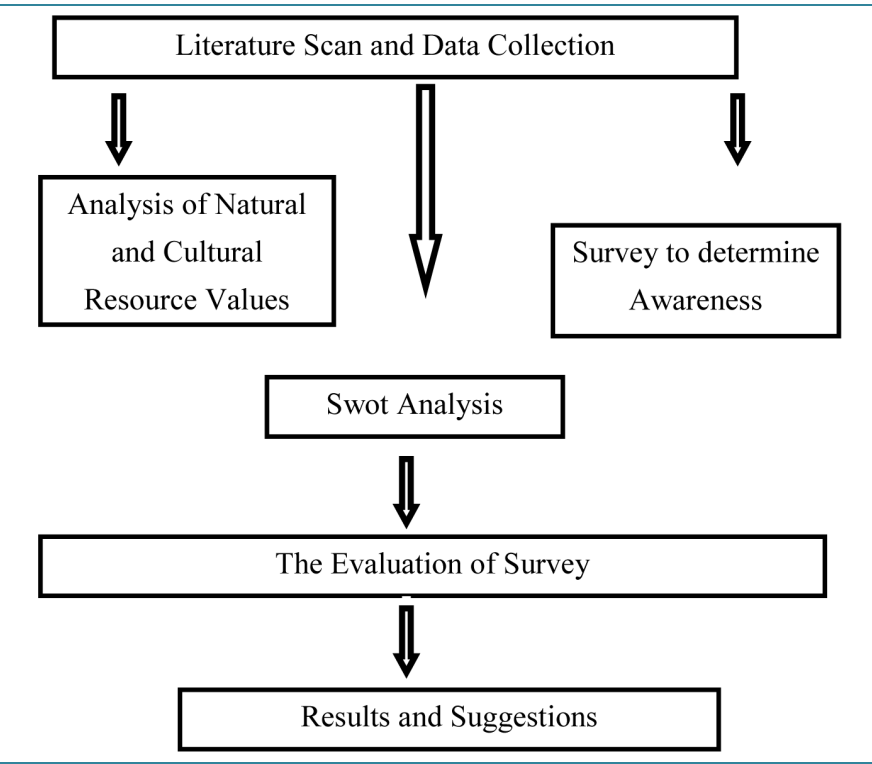




\section{Research Findings}

\subsection{Natural and Cultural Characteristics of the Areas}

While Ölüdeniz-Kıdrak Nature Park, a major touristic centre in Fethiye and located within the boundaries of Ölüdeniz, was a one-day Forest Recreation Area in 1978, later, it was declared with the agreement of the Ministry dated 12.29.1983 and numbered MP.1/5 - 311 as a Natural Park, and declared as a 1st degree Natural Protected Area with the agreement dated 11.13.1982 and numbered A-4020 by the Supreme Council of Immovable Cultural and Natural Heritage. The borders of the Nature Park are also within the boundaries of Fethiye-Gocek Special Environmental Protection Area (Figure 2). Containing a combination of three different protection statuses, Ölüdeniz-Kıdrak Natural Park was where our study was conducted. According to the National Parks Act No. 2873; Nature Park; represents components of nature featuring vegetation and wildlife, appropriate for recreation and entertainment of the public in the integrity of the landscape.

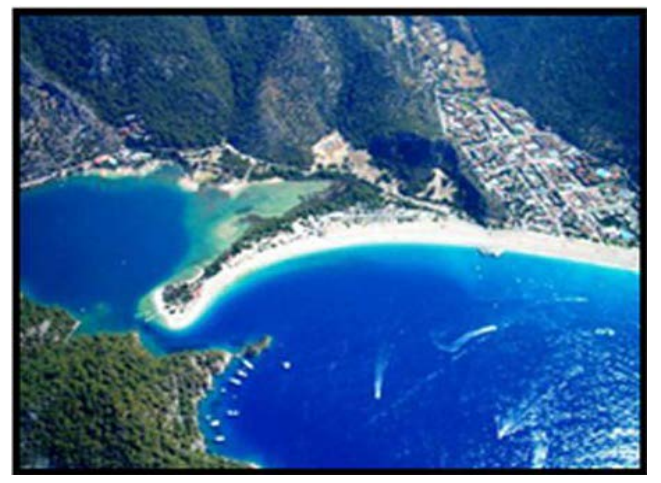

(a)

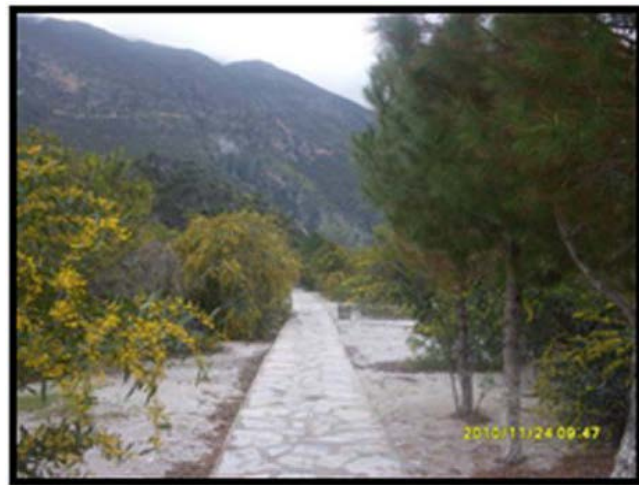

(c)

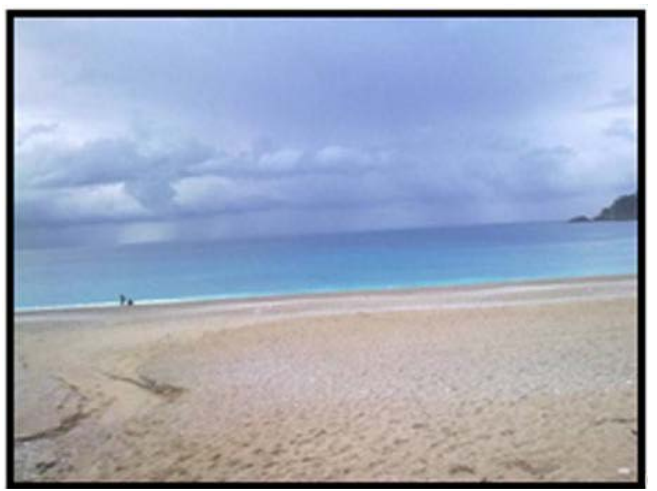

(e)

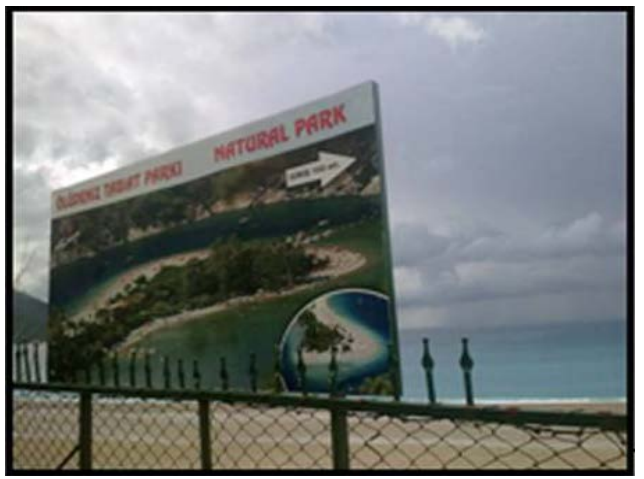

(b)

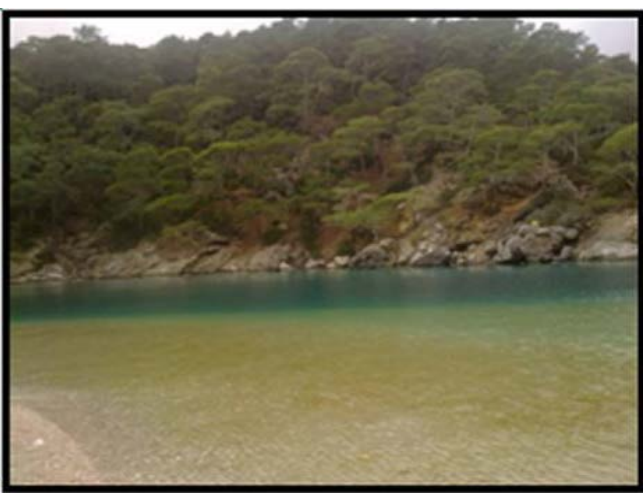

(d)

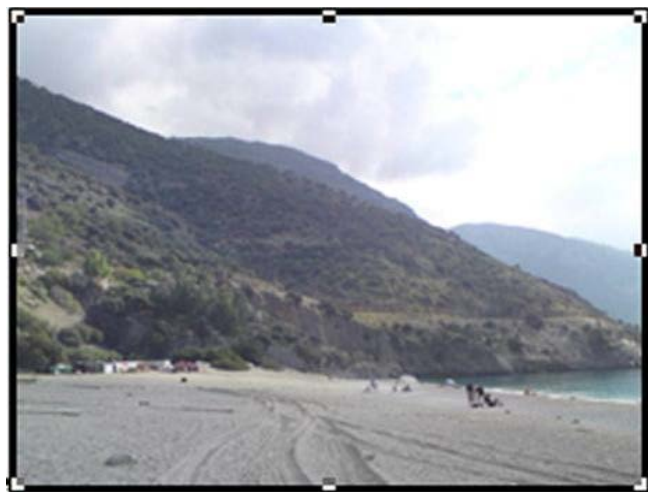

(f)

Figure 2. Various views of Ölüdeniz Natural Park; (a) The overall appearance of Ölüdeniz-Kıdrak Natural Park; (c) The route to the lagoon; (d) Ölüdeniz Lagoon; (e)-(f) Belcekız Beach. 
According to the Regulations on the Identification and Registration of Immovable Cultural and Natural Heritages requiring protection, enacted in 1989; Natural Site; is defined as "the areas above ground or under water that belong to geological eras and the prehistoric and historic periods and must be protected in terms of their rarity, features or beauty".

Special Environmental Protection Area are the regions; on the other hand, are the areas-pristine and under the pressure of investment-that are important to maintaining the elements of biological diversity, host the habitats of the species with threatened original ecosystems, arouse special interest in scientific, cultural and academic terms, bear international, national and regional values, harbour unique and rare ecosystems and species, have a high representativity of the area, host diversity in the area in terms of species and ecosystems, represent historical, cultural and archaeological significance and that offer specific landscape value [9].

Ölüdeniz-Kıdrak Nature Park, along with Kıdrak Forest Recreation Place, covers an area of 950 Ha. The resource values in the Natural Park can be listed as:

- Ölüdeniz Lagoon;

- Kidrak Beach;

- Spectacular views of coastal beauty;

- Geological and geomorphological features of interest;

- Rich flora and fauna;

- Pine forests;

- The archaeological remains;

- Landscape beauty and,

- Leisure, entertainment facilities.

The plants forming the Natural Park flora are as follows: Myrtus communis, Nerium oleander, Vitex agnus, Acacia cyanophlla, Olea europea, Juniperus harizontalis, Pinus brutia, Pistacia lentiscus, Washingtonia filifera, Phoenix canariensis, Quercus ilex and many shrub plants. And, certain species in the Natural Park fauna can be listed as: Partridges (Alectoris chukar), Swallows (Hirunda rustica), Woodpeckers (Dendrocopos mayor), starlings (Sturnus vulgaris), Tree Sparrows (Passer montanus), Sparrowhawks (Accipiter nisus), Hawks (Buteo buteo), Owls (Asio otus), crows (Corvus corax), wild boars (scrofa scrofa), foxes (vulpes), and rabbits (Lapus aeropaeus) [10].

The calcareous rocks in the Lagoon of Ölüdeniz and in the immediate vicinity of it are generally composed of carbonate units such as dolomitic limestone and dolomite. These structures have created important factors in the formation and development of Ölüdeniz Lagoon. Ölüdeniz Lagoon was formed as a result of the subsidence of coastal caves. The underwater cave formed on the fault line that intersected the shore, grew with time and formed the circular structure lagoon by subsiding. Also in the field are remains dating from the 8th century [5]. Various arrangements have been made in the nature park to meet the entertainment and recreational needs of the public. There are units of shower, toilet and dressing cabins and two restaurants at various points in the park on the route leading to the Lagoon. There is also a parking space for 300 vehicles. The number of visitors coming to the park daily during the tourist season reaches 5000. The Natural Park, along with its unique natural beauty, allows many recreational activities. We may list them as; Hiking, Amateur Line Fishing, Cycling Trips, Camping, Photo Safari, Botanical Tourism, Air Sports, Marine Activities.

Ölüdeniz-Kıdrak Natural Park has the potential of intensive use by domestic and foreign tourists during each touristic season. At this stage of the study, the SWOT analysis for Ölüdeniz-Kıdrak Natural Park is carried out. SWOT Analysis Technique is an analysis method used in decision-making at planning and management phase by identifying, in advance, the opportunities and threats that can be encountered in the future along with the available strengths (advantages) and weaknesses (disadvantages) about the subject. The results of the SWOT analysis for the Natural Park are given in Table 2.

\subsection{Survey Evaluation for Assessing the Awareness Levels of Domestic Tourists on Conservation Status}

In July 2013, a one-to-one survey was conducted with 100 domestic tourists randomly selected in the Natural Park in order to examine the awareness level on protected areas forming the main objective of the study. In the study, "SPSS 11.5" statistical software package was used and the non-parametric tests were applied. First, all the data was evaluated on percentage distribution (Table 3), then the significance control of the difference between 
Table 2. SWOT analysis for Ölüdeniz-Kıdrak Natural Park.

\begin{tabular}{|c|c|}
\hline Strengths & Weaknesses \\
\hline $\begin{array}{l}\text { - } \text { Climate, natural resources and pristine environment } \\
\text { - } \\
\text { - } \quad \text { Ölüdeniz Lagoon } \\
\text { - } \quad \text { Pristine natural areas } \\
\text { - } \quad \text { Sea coasts } \\
\text { - Offering many activities such as Nature walks, study tours, } \\
\text { - } \quad \text { mountain sports, rafting, photo safaris, bird and butterfly } \\
\text { - } \quad \text { Its boving uniquely beautiful and natural landscapes } \\
\text { - }\end{array}$ & 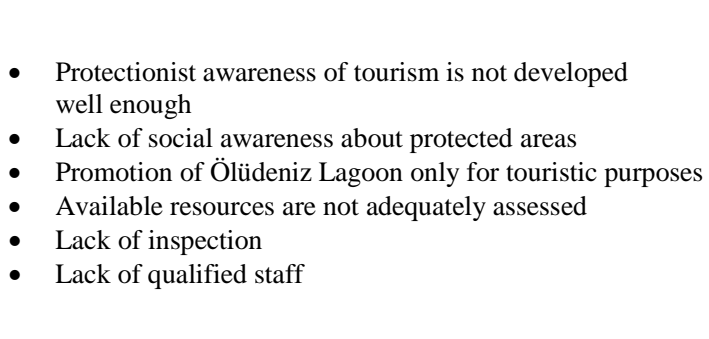 \\
\hline Opportunities & Threats \\
\hline 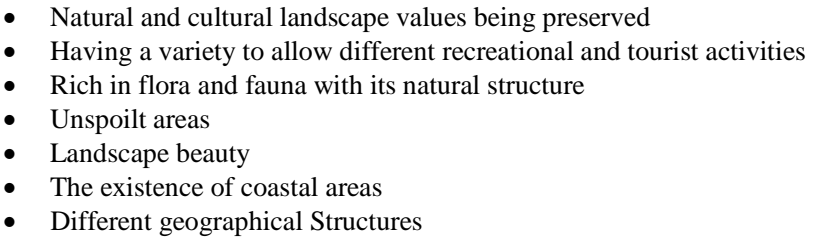 & $\begin{array}{l}\text { - } \quad \text { The corruption of natural and cultural texture } \\
\text { - } \quad \text { Marine pollution, destruction of coastal areas } \\
\text { - } \quad \text { Solid waste pollution } \\
\text { - } \quad \text { Exceeding the carrying capacity } \\
\text { The crowd particularly at the lagoon during the tourist } \\
\text { season and consequently the corruption of natural } \\
\text { environment }\end{array}$ \\
\hline
\end{tabular}

Table 3. Percentage distribution of responses to survey questions.

\begin{tabular}{|c|c|}
\hline Question 1: Gender & $\%$ \\
\hline 1. Female & 54 \\
\hline 2.. Male & 46 \\
\hline Question 2: First Visit to the Nature Park & $\%$ \\
\hline 1. Yes & 73 \\
\hline 2. No & 27 \\
\hline Question 3: Reason for Coming & $\%$ \\
\hline 1. Natural beauty & 13 \\
\hline 2. Sports activities & 6 \\
\hline 3. To see Ölüdeniz & 46 \\
\hline 4. all & 35 \\
\hline Question 3: From what region & $\%$ \\
\hline 1. Eastern-Southeastern Anatolia & 17 \\
\hline 2. Mediterranean-Aegean & 28 \\
\hline 3. Black Sea & 5 \\
\hline 4. Marmara & 27 \\
\hline 5. Central Anatolia & 23 \\
\hline Question 4: Environmental Quality of the Nature Park & $\%$ \\
\hline 1. Poor & 12 \\
\hline 2. Good & 70 \\
\hline 3. Very good & 18 \\
\hline Question 5: Nature Park appreciation status & $\%$ \\
\hline 1. Yes & 95 \\
\hline 2. No & 5 \\
\hline Question 6: Environmental Problems of the Nature Park & $\%$ \\
\hline 1. Lack of maintenance & 2 \\
\hline 2. Traffic and parking & 38 \\
\hline 3. Equipment and roads & 11 \\
\hline 4. Solid waste & 6 \\
\hline 5. All & 43 \\
\hline Question7: Knowledge about conservation statuses & $\%$ \\
\hline 1. Yes & 24 \\
\hline 2. No & 76 \\
\hline Question 8: Which conservation status is known & $\%$ \\
\hline 1. Nature parks & 15 \\
\hline 2. Special Environmental Protection Area & 6 \\
\hline 3. Natural Site & 3 \\
\hline 4. I do not know & 76 \\
\hline
\end{tabular}


the two percentages was performed with Chi-Square test, and the results related to the objective of the study were interpreted.

The compliance of the observed frequencies belonging to different categories of a certain variable with the expected frequencies is investigated through Chi-Square conformity test [11]. For this reason, chi-square test was found to be the most suitable analysis technique for survey.

$54.0 \%$ of the respondents were female and $46.0 \%$ of them were male. While $73.0 \%$ of the respondents were in the area for the first time, $27.0 \%$ of them had previously been there. Of all the reasons for coming to the area; visiting Ölüdeniz comes first (46\%), while performing sports activities comes last (6\%). When we look at the distribution of geographical regions that the domestic tourists came from; It is revealed that $17.0 \%$ of them were from the East and Southeast Anatolia regions, 28.0\% of them were from the Mediterranean and Aegean regions, $5.0 \%$ were from the Black Sea region, $27.0 \%$ of them were from the Marmara region and 23\% of them were from Inner Anatolia region. We can see that most came from the immediate regions in the regional distribution. The majority of the respondents (95.0\%) stated that they liked the Natural Park. The environmental quality in the nature park was considered good in general (70\%), the environmental issues, traffic density and parking problems in the Natural Park (38\%), litter and solid waste problems (6\%), whether the equipment and auto-pedestrian paths respond to the need (11\%).

As for the question about the awareness that the Natural Park was a "protected area", the majority of the respondents (71.0\%) stated that they were not aware that the area was a protected one. $6 \%$ of the respondents who knew that it was a "protection area" stated that they knew that it was a Special Environmental Protection Area; $15 \%$ of them stated that they knew that it was a Natural Park and 3\% of them stated that they knew that it had a natural site status.

The results found to be significant according to the results of Chi-Square test applied for the survey study on SPSS 15.0 program are as follows: There was a statistically significant relationship on a significance level of 0.046 between gender and first-time visiting factors; on a significance level of 0.020 between gender factor and nature park environmental quality; on a significance level of 0.004 between first time visiting and the reason for the visit; and on a significance level of 0.001 between first time visit and the regions they come from. Additionally, we found a relationship on a significance level of 0.026 between first time visitors and the conservation statuses; and a relationship on a significance level of 0.024 between the knowledge about these statuses and what they are. When we look at the evaluation of the results suitable for our study objective; we can see that first time visitors to the area come to the area in order to see Ölüdeniz; the majority of the first time visitors to the area are not aware that it is a protected area; and those who are aware that it is a protected area do not have exact knowledge about its protection status.

\section{Discussion and Conclusions}

There are nine basic objectives of protected areas. These are; scientific research, conservation of the wild areas, conservation of species, ecosystems and genetic diversity, ensuring the continuity of environmental services, conservation of natural and cultural values, tourism and recreation, nature education, sustainable use of natural resources, ensuring sustainability of cultural, traditional and folkloric features [10]. The achievement of these objectives can only be possible through the training activities intended for the users. As a result of the deficiencies in implementing the physical criteria; land-use planning on a national, regional and local scale lose its effectives on planning decisions in a short time, and it leads to the increase of pressure on natural resources, the loss of environmental values and the off-plan developments in land-use [1].

Ölüdeniz-Kıdrak Nature Park Long Term Development Plan has been prepared to ensure the balance of protection and utilization within the boundaries of Ölüdeniz-Kıdrak Nature Park, which was declared as a Natural Park by the Ministerial approval dated 12.29.1983 and numbered MP.1/5 - 311. In order to achieve the objectives in Long Term Development Plan, it is essential that these plans be implemented and inspected by experts. Otherwise, there will be off-plan developments. These objectives are listed below;

- To protect the resource values of Ölüdeniz-Kıdrak Natural Park;

- To ensure the continuity of Ölüdeniz Lagoon, located within the boundaries of the Natural Park, and the Strait of Kumburnu, which provides the connection of this lagoon with the open sea, by considering the balance of protection and utilization;

- To ensure the continuity of ecological, biological (flora and fauna), geological, geomorphological, landscape 
values and natural structure, belonging to the area, which constitute its main source values;

- To ensure the continuity of archaeological sites, which is one of the cultural values of the Nature Park;

- To ensure the sustainability of the beauty of coastal landscapes, geological and geomorphological features, pristine flora and fauna and high recreational value of the Nature Park;

- To take the necessary measures to reduce the loss of biodiversity which is/will be formed by human pressures, other uses and demands;

- To ensure the continuity of the resource values, the reason for its declaration as a Nature Park, and to transfer them to future generations;

- To prevent the environmental pollution affecting the ecosystems in the area;

- To protect the species, natural habitats in the area and to support the local and regional economy with environmentally friendly practices in the area;

- To identify sustainable use opportunities by defining the interaction between the existing human use and the natural resources in the area [12].

When the protected areas, which were declared so with the aim of ensuring the continuity of our natural and cultural resource values and biodiversity, are used by people who do not have a certain level of awareness; it will not be possible to state that the protection factor is provided effectively. As a matter of fact, when all the protection movements based on the future of societies and the sustainability of natural resources remain outside the society, they cannot fulfil the essential function of theirs. As a result of the emerging results from this study investigating the level of awareness on conservation status; it can be seen that the local people are not aware of the concept of protected areas and conservation statuses at all. In the tourism activities that the trio of see, visit and have fun have become more dominant, especially conservation status and our protected resource values should be evaluated by a protectionist tourism approach. For this, of course, the first step should be awareness. The fact that the protected area status of Ölüdeniz, which has a worldwide reputation, is known by very few people at the same has mainly stemmed from the fact that promotions are done mainly in terms of tourism. The promotion of our protected resource values used for tourism promotion should done not only to ensure the attract tourists, but also to raise and establish conservation awareness.

As protectionist approaches can only be managed through people having this awareness, activities for Ölüdeniz-Kıdrak Natural Park should be done particularly in the tourist season to promote the resource values of the area and the conservation concept. If an effective awareness is not ensured for our protected areas, which were declared with many legal regulations, the work needed to raise public awareness for our protected areas should be done to maintain a conservation-utilization balance and to prevent endangering the sustainable use of these area.

\section{References}

[1] Akten, M., Yılmaz, O. and Gul, A. (2009) Alan Kullanım Planlamasında Rekreasyonel Alan Kullanım Olçutlerinin Belirlenmesi: Isparta Ovası Orneği. Suleyman Demirel Universitesi Orman Fakultesi Dergisi, Sayı, 2, 119-133.

[2] Gül, A. and Sahin, C. (2010) Ulkemizdeki Dogal Sit Alanlarının Mevcut Durumu Analizi (Bodrum Yarımadası Ornegi) III. Ulusal Karadeniz Ormancilık Kongresi. IV Sayfa, Cil, 1564-1574.

[3] Gunes, G. (2011) Korunan Alanların Yonetiminde Yeni Bir Yaklaşım: Katılımcı Yonetim Planları. Ekonomi Bilimleri Dergisi, Cilt 3, No. 1.

[4] Atmaca, M. (2006) Korunan Alanlar ve Koruma Statuleri. Hatay’da On Sicak Gun. Mustafa Kemal Universitesi, Yayın No. 19.

[5] Sanver, İ. (2008) Kentsel Yayılmanın Cevreye Etkilerinin Uzaktan Algılama Yontemiyle Belirlenmesi. Ölüdeniz (Fethiye) Ornegi. Fen Bilimleri Enstitusu, Cevre Bilimleri Anabilim Dalı, Yuksek Lisans Tezi, Ankara.

[6] Kocan, N. (2011) Murat Dagı'nın Ekoturizm Potansiyelinin Belirlenmesi Uzerine Bir Arastırma. Igdir Universitesi Fen Bilimleri Enstitusu Dergisi, 1, 69-75.

[7] Orhan, T. (2008) Uzundere İlcesi ve Yakın Cevresinin Ekoturizm Potansiyelinin Belirlenmesi ve Sınıflandırılması. Fen Bilimleri Enstitüsü, Peyzaj Mimarlıgı Anabilim Dalı, Yuksek Lisans Tezi, Erzurum.

[8] Uzgoren, N. and Uzgoren, E. (2007) Dumlupınar Universitesi Lisans Ogrencilerinin Memnuniyetini Etkileyen Bireysel Ozelliklerin Istatistiksel Analizi-Hipotez Testi, Ki-Kare Testi ve Doğrusal Olasılık Modeli.

[9] Keskin, T.A. and Sarac, B. (2008) Doga Koruma ve Planlama. Planlama, TMMOB Sehir Plancıları Odası Yayını, Sayı, 42, 73-87. 
[10] Anonymous (2013) Yeryuzu Cenneti Mugla. Mugla İli Doga Turizmi Master Planı. 2013-2023. IV. Bolge Mudurlugu.

[11] Eymen, U.E. (2008) SPSS 15.0 Veri Analiz Yontemleri.

[12] Anonymous (2013) http://turuncpeyzaj.com/T_ICerik.aspx?m=65 
Scientific Research Publishing (SCIRP) is one of the largest Open Access journal publishers. It is currently publishing more than 200 open access, online, peer-reviewed journals covering a wide range of academic disciplines. SCIRP serves the worldwide academic communities and contributes to the progress and application of science with its publication.

Other selected journals from SCIRP are listed as below. Submit your manuscript to us via either submit@scirp.org or Online Submission Portal.
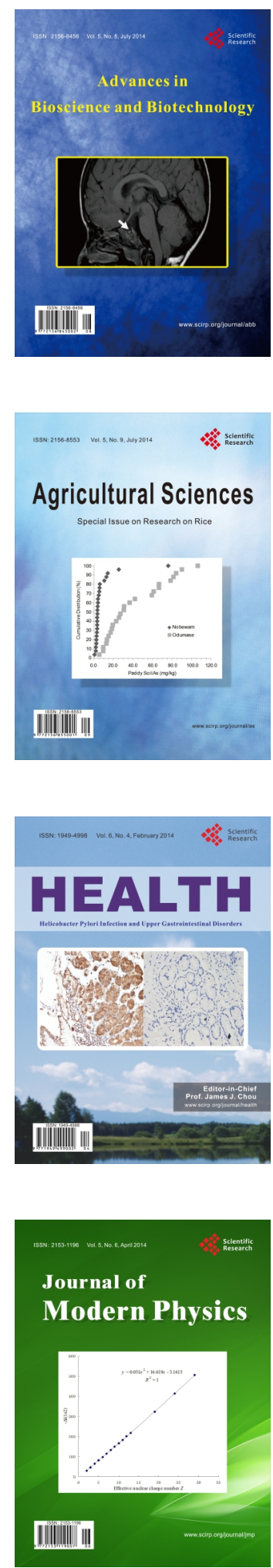
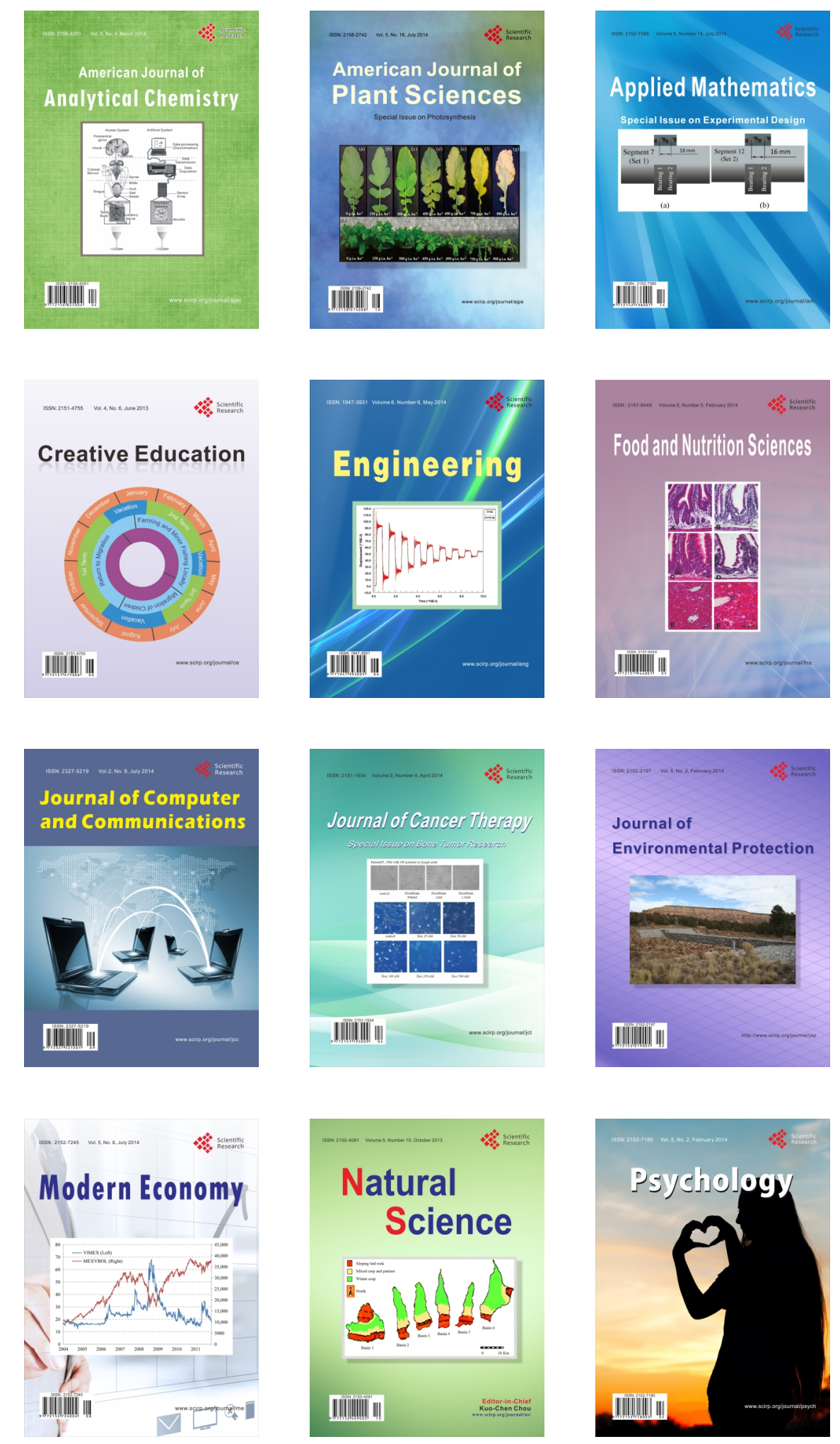